\title{
Rising Lung Cancer Deaths among Younger Individuals: Lung Carcinoma in a Patient at the Age of 26
}

\author{
Z. Kocak ${ }^{a} \quad$ M. C. Uzal ${ }^{a} \quad$ K. Uygun ${ }^{b}$ \\ ${ }^{\text {a }}$ Department of Radiation Oncology, \\ b Department of Medical Oncology, Trakya University, Edirne, Turkey
}

We read with interest the report on carcinoma of the lung in a young non-smoker by Filik et al. [1]. They described a 32-yearold man with locally advanced (III B) adenocarcinoma of the lung and noted that when a young patient complains of pulmonary symptoms and shows abnormal findings on X-ray, lung cancer should be taken into consideration as a differential diagnosis. In agreement with their observation, we think that this is the case even in patients aged younger than 30 years. A reduced mortality from other diseases, and an increase in cigarette smoking contribute to the rise in incidence and mortality rates from lung cancer in the developing countries [2].

A 26-year-old male patient was admitted in August 2001 with a 2-month history of cough, mild dyspnea, loss of appetite, leftsided posterior chest pain. He had smoked one pack of cigarettes daily for 9 years, but had given up the habit 2 years before admission; he also had a history of passive smoking. However, he had no family history of lung cancer or pulmonary tuberculosis. Chest X-ray showed a large opacity in the left perihilar region. Computed tomography (CT) of the thorax revealed a left hilar mass extending from the hilum along the bronchial tree of the left lower lobe. Histological examination after bronchoscopic biopsy revealed a small-cell lung carcinoma (SCLC). Bone scan showed multiple areas of increased uptake. Extensive SCLC was diagnosed (T3 N2 M1).

During the 2-month period following diagnosis, the patient received chemotherapy (etoposide plus cis-platinum every 3 weeks) and also palliative radiotherapy for metastatic bone lesions. After 3 cycles, CT scan of the chest revealed a partial regression and the patient was given 3 more cycles of chemotherapy. In spite of achieving partial response, the patient showed progressive disease 2 months after completion of chemotherapy. It was concluded that the patient had early progressive disease and no treatment other than the supportive was given. The patient died of disease progression 6 months after diagnosis. Mostly, lung cancer occurs after the fifth decade of life. Only $0.1-0.4 \%$ of all lung cancer cases occur at ages below 30 years [3]. However, the increase in cigarette smoking among teenagers, especially girls, will result in rising lung cancer deaths among younger individuals [4]. Hegmann et al. [5] noted a significantly higher risk for lung cancer in patients who began smoking before the age of 20 than in those who began later. It has also been reported that a positive relationship between smoking and p53 gene alteration exists in young adults with lung cancer [6]. Despite a short smoking history with early initiation age in the current case, tumor cells were positive for mutant p53 protein.

Reviewing the literature, there were only 2 published clinical series regarding lung cancer patients younger than 30 years [7, 8]. As in younger patients $(<40-50$ years $)$, there is a high proportion of female patients and adenocarcinoma histology, and advanced disease at diagnosis (excluding the low-grade malignancy), also a relatively poor prognosis seems to be common. Although SCLC is rare in the young age group, it carries a very poor prognosis. Therefore, when a young patient presents with pulmonary symptoms and abnormal findings on X-ray, lung cancer should be considered in differential diagnosis.

\section{References}

1 Filik L, Ozyilkan O: Adenocarcinoma of the lung in a 32-year-old man: Is it worthwhile to check for lung cancer in young adults? Onkologie 2002;25:64.

2 Bilello KS, Murin S, Matthay RA: Epidemiology, etiology, and prevention of lung cancer. Clin Chest Med 2002;23:1-25.

3 Emori Y, Kiura K, Yoshino T, Notohara K, Tsuchida T, Yokoyama M, Nogami N, Kataoka M, Ueoka H, Harada M: Very young patient with peculiar squamous cell carcinoma of the lung. Intern Med 1999;38:979-983.

4 Zang EA, Wynder EL: Differences in lung cancer risk between men and women: examination of the evidence. J Natl Cancer Inst 1996;88:183-192.

5 Hegmann KT, Fraser AM, Keaney RP, Moser SE, Nilasena DS, Sedlars M, Higham-Geren L, Lyon JL: The effect of age at smoking initiation on lung cancer risk. Epidemiology 1993;4:444-448.

6 Kashii T, Mizushima Y, Lima CE, Noto H, Sato H, Saito H, Kusajima Y, Kitagawa M, Yamamoto K, Kabayashi M: Studies on clinicopathological features of lung cancer patients with K-ras/p53 gene alterations: Comparison between younger and older groups. Oncology 1995;52:219-225.

7 Mizushima Y, Yokoyama A, Ito M, Manabe H, Hirai T, Minami H, Anzai Y, Sato H, Kusajima Y, Ymashita R, Kobayashi K, Sugiyama S, Kobayashi M: Lung carcinoma in patients age younger than 30 years. Cancer 1999;85:1730-1733.

8 Whooley BP, Urschel JD, Antkowiak JG, Takita H: Bronchogenic carcinoma in patients age 30 and younger. Ann Thorac Cardiovasc Surg 2000;6:86-88.

\begin{tabular}{|c|c|}
\hline KARGER & (C) 2004 S. Karger GmbH, Freiburg \\
\hline $\begin{array}{l}\text { Fax +497614520714 } \\
\text { E-mail Information@Karger.de } \\
\text { www.karger.com }\end{array}$ & $\begin{array}{l}\text { Accessible online at: } \\
\text { www.karger.com/onk }\end{array}$ \\
\hline
\end{tabular}

